\title{
Stratigraphic Architecture and Lithofacies Analysis: Evidence for Development of the Pliocene-Holocene Taichung Foreland Basin, Central Taiwan
}

\author{
Chung-Yen $\mathrm{Kao}^{1, *}$, Eason Hong ${ }^{1}$, Ho-Shing $\mathrm{Yu}^{2}$, and Sam Wong ${ }^{1}$ \\ ${ }^{1}$ Institute of Applied Geosciences, National Taiwan Ocean University, Keelung, Taiwan \\ ${ }^{2}$ Institute of Oceanography, National Taiwan University, Taipei, Taiwan
}

Received 2 December 2011, accepted 11 September 2012

\begin{abstract}
The Taichung foreland basin, sub-basin of the Taiwan foreland basin, has developed since Pliocene. We studied stratigraphic architecture and the lithofacies of the Taichung basin in detail. We recognized eleven lithofacies, which are grouped into ten facies associations. Based on facies association analysis, we suggest that the development of the Taichung basin can be divided into four stages accompanied by syn-depositional deformation characterized by westward propagating thrust faults.

Prior to $2.78 \mathrm{Ma}$, the basin was characterized by offshore environment during underfilled stage. Later, the Shuangtung Fault located to the east of the Western Foothills began to thrust westward and uplifted the Tertiary strata, which supplied sediments to basin between the Shuangtung and Chelungpu faults in initial filled stage. About $1 \mathrm{Ma}$, the Chelungpu Fault started to thrust westward and uplifted the Western Foothills, which shed fluvial sediments to fill basin between the Chelungpu and Tachia faults. After 0.46 Ma, the Tachia Fault began to thrust westward and strata immediately to the east of the Tachia Fault were uplifted to form ramps, producing Houli and Tatushan tablelands. The basin-filling reached the overfilled stage when the Chingshui Coastal Plain is dominated with fluvial facies.

The Taichung foreland basin is bounded by Tachia and Shuangtung faults with the Chelungpu Fault in the middle and formed by active, sequentially propagating westward thrust faults from Pliocene to Pleistocene. The youngest Tachia Fault carried the piggyback basin in front of the older Chelungpu Fault, representing similar style to piggyback basins of the Po Basin and the Ebro Basin in Europe.
\end{abstract}

Key words: Taiwan, Foreland basin, Piggyback basin

Citation: Kao, C. Y., E. Hong, H. S. Yu, and S. Wong, 2013: Stratigraphic architecture and lithofacies analysis: Evidence for development of the PlioceneHolocene Taichung foreland basin, central Taiwan. Terr. Atmos. Ocean. Sci., 24, 41-58, doi: 10.3319/TAO.2012.09.11.01(TT)

\section{INTRODUCTION}

A foreland basin is an elongate region of potential sediment accommodation that is adjacent to an orogenic belt (DeCelles and Giles 1996). Taiwan is located at the junction between the Ryukyu and Luzon Arcs (Fig. 1). The Taiwan orogen was a result of the oblique arc-continent collision between the Philippine Sea (PSP) and southeast margin of the Eurasian plates (EP) in Late Miocene-Early Pliocene (Suppe 1981). The load of the Taiwan orogen flexed down the foreland region in the southeastern edge of EP and formed

\footnotetext{
* Corresponding author

E-mail: stephencykao@gmail.com
}

the foreland basin to the west of the Taiwan orogen (Lin and Watts 2002). Based on distribution of sediment type and stratigraphic architecture, the Taiwan foreland basin can be divided into a mature foredeep in the north and a younger one in the south (Covey 1984). The former is mainly filled with fluvial sediments derived from the Taiwan orogen in a steady-state condition. The latter is mainly filled with deep marine offshore sediment derived from southwest part of the Taiwan orogen. The boundary between the north and south basins is located in Taichung. Chen et al. (1999) proposed a foreland basin model for the formation of sub-basins within the Taiwan foreland basin. The load of the Taiwan orogen has caused foreland subsidence to the west of the Taiwan 


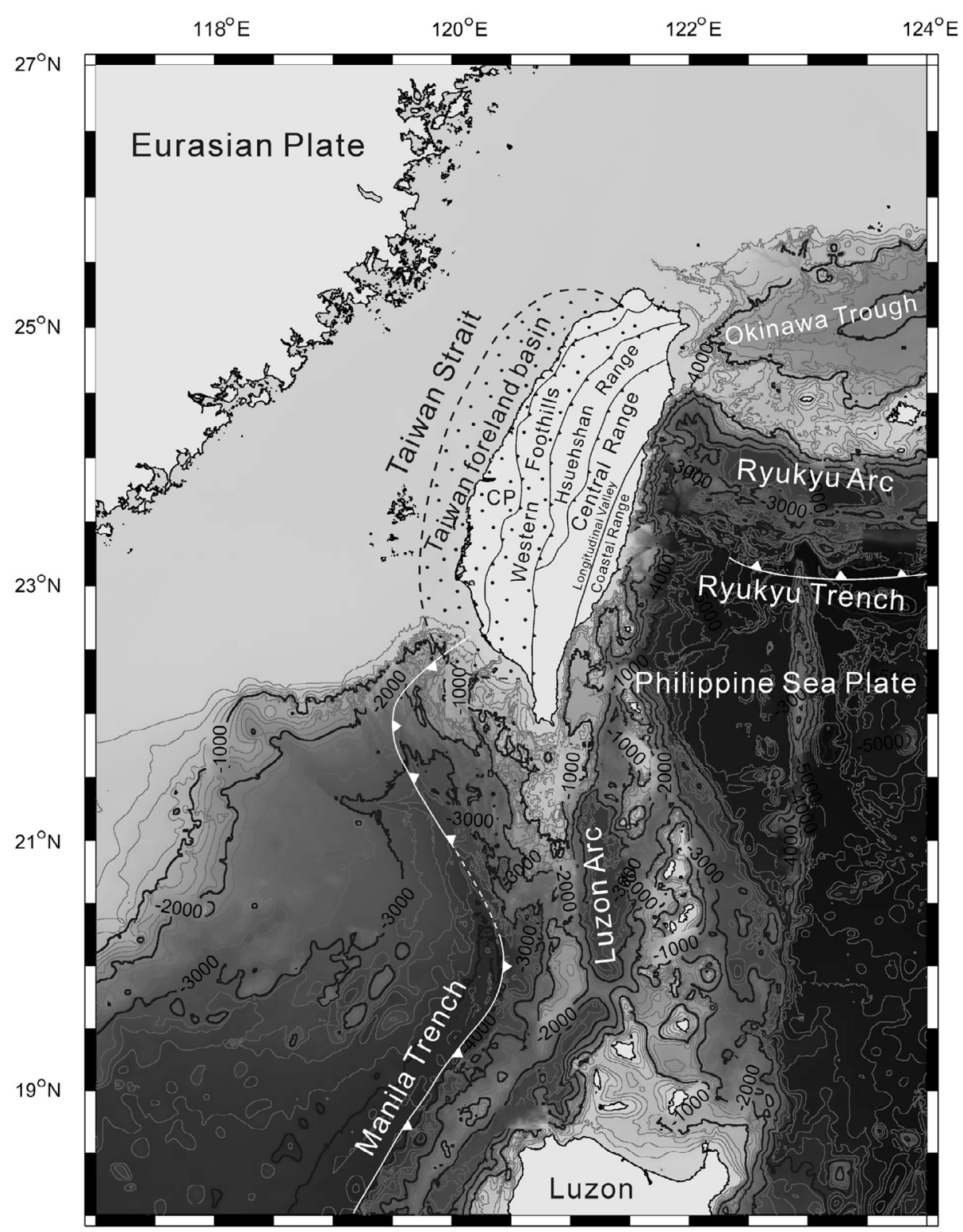

Fig. 1. Map of tectonic setting of Taiwan showing the paired Taiwan orogen and adjacent foreland basin. The western Taiwan foreland basin is primarily filled with Pliocene-Pleistocene sediment distributed in the Western Foothills, Coastal Plain and eastern part of Taiwan Strait. CP: Coastal Plain.

mountain belt and has resulted in various sub-basins that are accompanied by a series of westward propagating thrust faults. They proposed that the central part of the Taiwan foreland basin (Taichung foreland basin) resulted from thrusting of the Shuangtung and the Chelungpu faults. It has been recognized that the foreland sub-basins formed along the strike of the orogen (Covey 1984; Kumar et al. 2003) rather than sequentially normal to the strike of the orogen. Apparently, the model proposed by Chen et al. (1999) is different from that proposed by Covey (1986) for the Taiwan foreland basin. This contrast provides a room for better understanding of the evolution of Taiwan foreland basin in general and motivates us to concentrate to the refinement of the sedimentary evolution from underfilled to overfilled stages of the Taichung foreland basin in particular.

The Taichung foreland basin is in the west of the Shuangtung Fault (Fig. 2a) and extends farther westwards beyond the Changhua Fault and to the eastern part of the Taiwan Strait (Fig. 2b; Chen et al. 2001b). However, the sedimentary environments and depositional history of the sequences in the subsurface of coastal plain were not discussed by Chen et al. (1999, 2001b). The studies of depositional environments and lithofacies of the coastal plain should be integrated into the previous studies of Chen et al. $(1999,2001 b)$ to better understand the evolution of the Taichung foreland basin. Therefore, we provide new strati- 
(a)

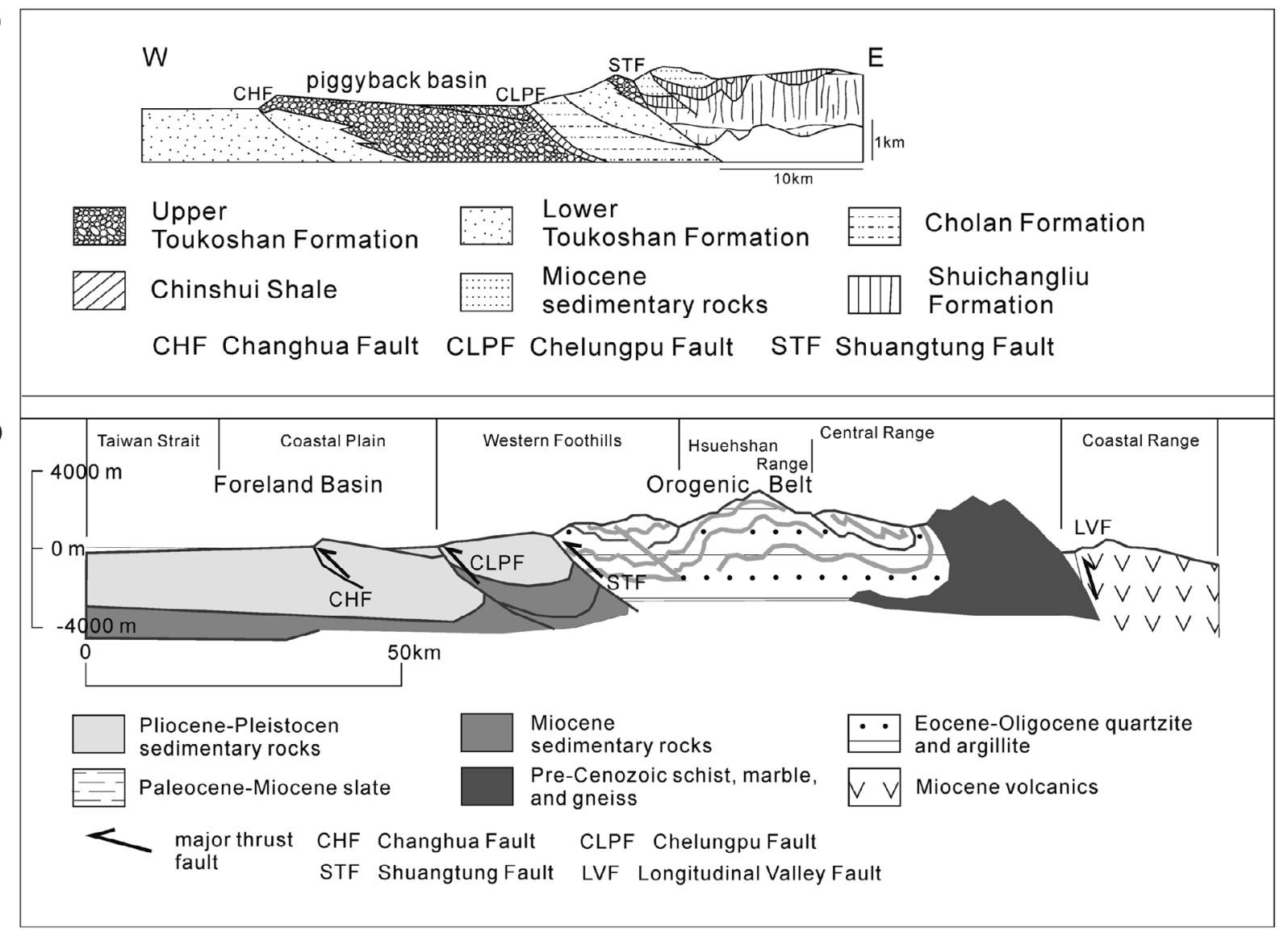

Fig. 2. Schematic cross-sections of central Taiwan show strata, structures and tectonostratigraphic elements of the foreland basin west of the Taiwan orogen. (a) Schematic cross-section mainly displays the stratigraphic architecture and a series of thrusting faults in the Taichung foreland basin. A piggyback basin is defined between CHF and CLPF. After Chen et al. (1999). (b) Schematic cross-section of central Taiwan showing main tectonostratigraphic elements and geological structures of Taiwan. The Taichung foreland basin located west of the Chelungpu Fault includes coastal plain and eastern part of the Taiwan Strait. After Chen et al. (2001b).

graphic data, including those in the subsurface of the coastal plain and piggyback basin in particular, in the study of Taichung foreland basin, ranging from its distal (Coastal Plain) to proximal parts (the Western Foothills), so that we could refine the interpretations of the basin formation. We propose a hypothesis of four stages of sediment filling evolution from underfilled to overfilled stages of the Taichung foreland basin in association with westward thrusting faults during Pliocene-Holocene.

\section{GEOLOGICAL SETTING}

\subsection{The West Taiwan Foreland Basin}

The western Taiwan foreland basin can be considered as a peripheral foreland basin according to Dickinson's (1974) definition. This basin is in the west of Taiwan orogen and extends from the Western Foothills to eastern Taiwan Strait (Covey 1984; Chou and Yu 2002) (Fig. 1). The western Taiwan foreland basin is mainly filled with PliocenePleistocene sediments which are characterized by coarsen- ing upwards from offshore fine deposits to fluvial coarse sediments (Covey 1984). This basin has been deformed by a series of thrust faults, propagating not only westwards but also parallel with the strike of Taiwan orogen (Lee et al. 1997; Chen et al. 2001b; Chiang et al. 2004). For example, the strata of the proximal Western Foothills adjacent to Taiwan orogen have been deformed by thrust faults, forming a wedge-top depozone. Active thrust faults carried piggyback basins westwards in central and southern part of Taiwan foreland basin (Chen et al. 1999; Chiang et al. 2004). The development of thrust faults influenced the depositional environments of sub-basins within the southwest Taiwan foreland basin (Lee et al. 1997).

\subsection{Study Area}

The study area lies within the central Taiwan and mainly in the Taichung foreland basin (Chen et al. 1999). The area is bounded to the north by the Da-an Stream, to the south by the Dadu Stream, to the east by the Shuang- 
tung Fault and to the west by shore line (Fig. 3). A series of thrust faults developed in the study area west of Taiwan orogen. They are the Shuangtung Fault (STF), the Chelungpu Fault (CLPF) and the Tachia Fault (TCF) from east to west, respectively (Lin et al. 2008). The Western Foothills is bounded by STF and CLPF mainly consists of uplifted Pliocene-Pleistocene strata. A piggyback basin lies in the area between the CLPF and the TCF. West of the piggyback basin are two tablelands, the Houli Tableland in the north and the Tadushan Tableland in the south.
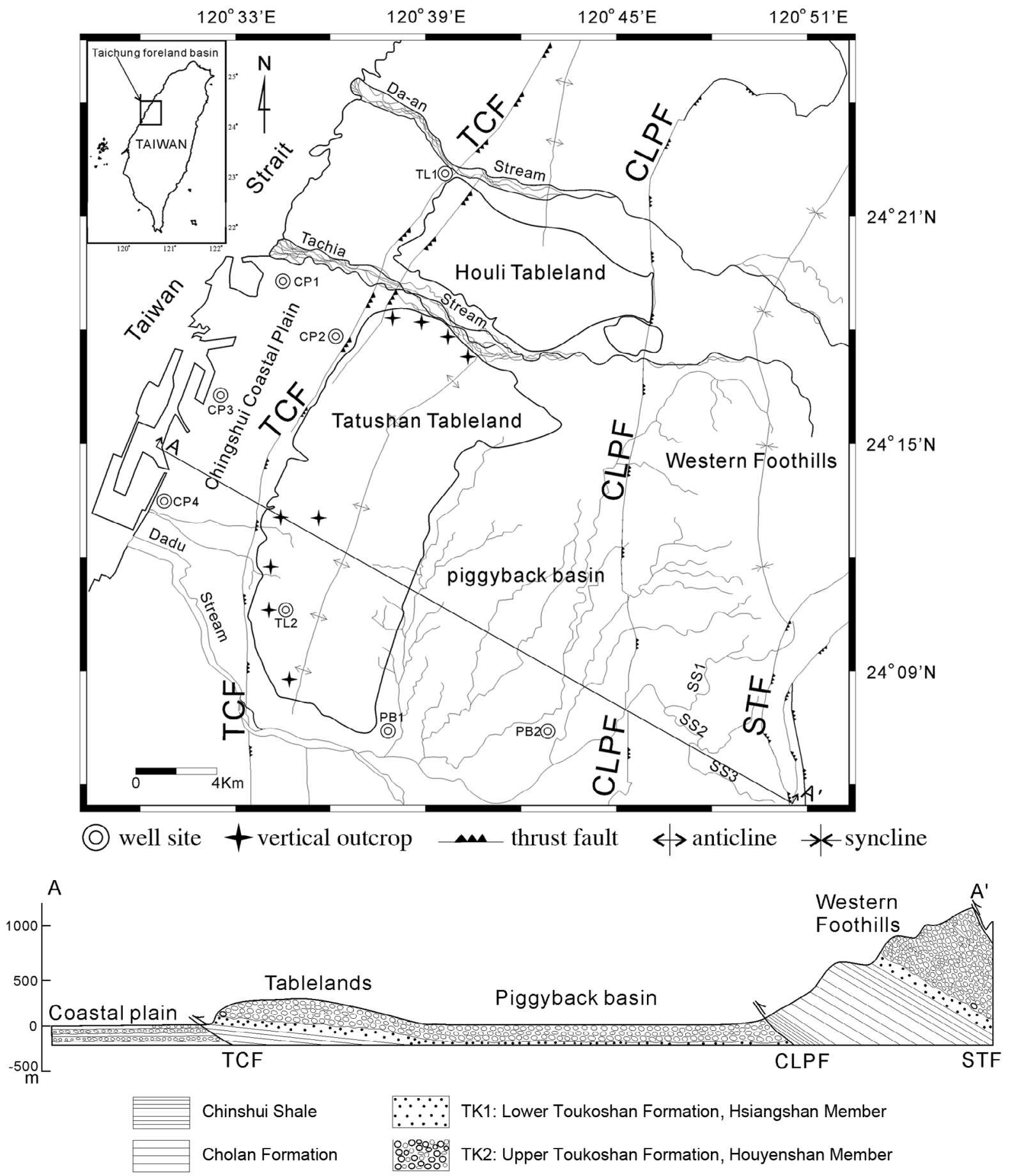

Fig. 3. Location map of the study area shows the Taichung foreland basin with major thrust faults, distinct morphological features of the Houli and Tatushan tablelands and a major depositional center (piggyback basin) between two thrust faults. Inset on left upper corner shows the location of the Taichung foreland basin in west Taiwan. Three surface sections and nine outcrops and well sites are displayed. Surface section: SS1: the Peikenchi section, SS2: the Toupienkengchi section, SS3: the Tungpienkengchi section. well site, vertical outcrop, anticline, TCF: Taichia Fault; CLPF: Chenglungpu Fault; STF: Shaungtung Fault. 
The stratigraphic units of the Western Foothills of the Taichung foreland basin are, from old to young, the Chinshui shale, the Cholan Formation and the Toukoshan Formation (Ho 1986; Yang 1997). The Chinshui shale mainly comprises very thick dark gray shale (Fig. 4a) with thin intercalated sand beds. This formation is interpreted as off shore marine sediments. The Cholan Formation comprises thick shale with thin to medium sand layers in its lower part, whereas in the upper parts of the formation comprises thick mudstone intercalated with amalgamated sandstone or interbedded thin sandstone and mudstone. The sandstone beds increase in thickness and abundance in upper part of the Cholan Formation. The uppermost sandstones are embedded with scattered pebbles (Fig. 4b). The Formation is also characterized by upward-coarsening lithology and is interpreted as deposits of inner offshore and shoreface environments (Ho 1986; Chen et al. 2001b). The Toukoshan Formation is dominated by fluvial sediments, which can be separated into two parts: the Hsiangshan Member in the lower part and the Houyenshan Member in the upper part (Ho 1986; Yang 1997). The former contains amalgam- ated sandstones, siltstones and shale. The later consists of thick beds of conglomerate with lenticular sandstones and mudstones (Fig. 4c). Previous studies of planktonic foraminiferal fauna suggested that the age of this formation is from the late Pliocene to early Pleistocene (Huang 1981). The middle to upper parts of the Cholan Formation contains nannofossils which ages are younger than 1.6 Ma (Chi et al. 1984; Yang 1997).

\section{METHOD AND DATA}

This paper presents sedimentology studies of the Pliocene-Holocene strata of the Taichung foreland basin based on lithofacies analysis (Reading 1986; Boggs 2001). Facies association can be thought of as groups of facies that occur together and are closely or environmentally related. The key to environmental interpretation is to analyze all of the facies together, that is, to study the entire stratigraphic successions in which facies occurred. The vertical succession and lateral variation in facies can contribute environmental information as much as the characteristics of the facies themselves (a)

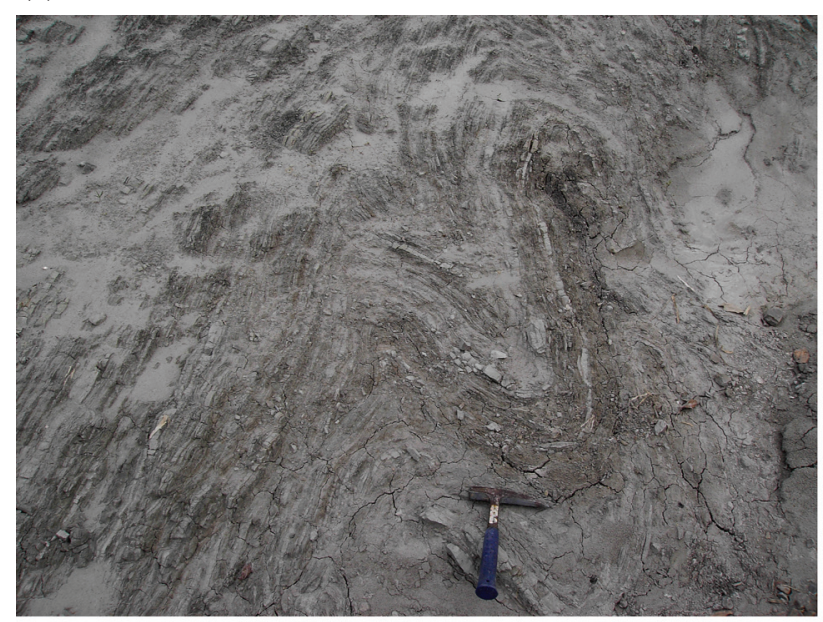

(c)

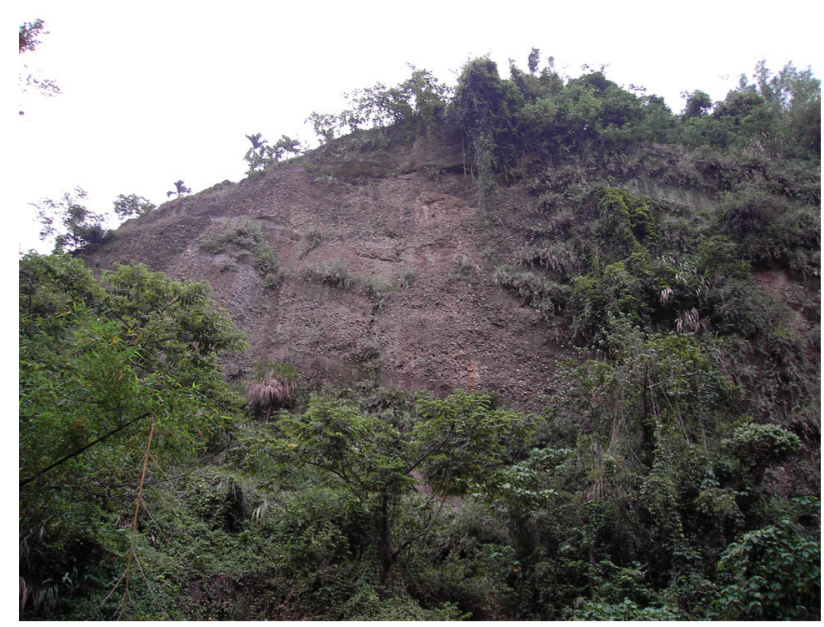

(b)

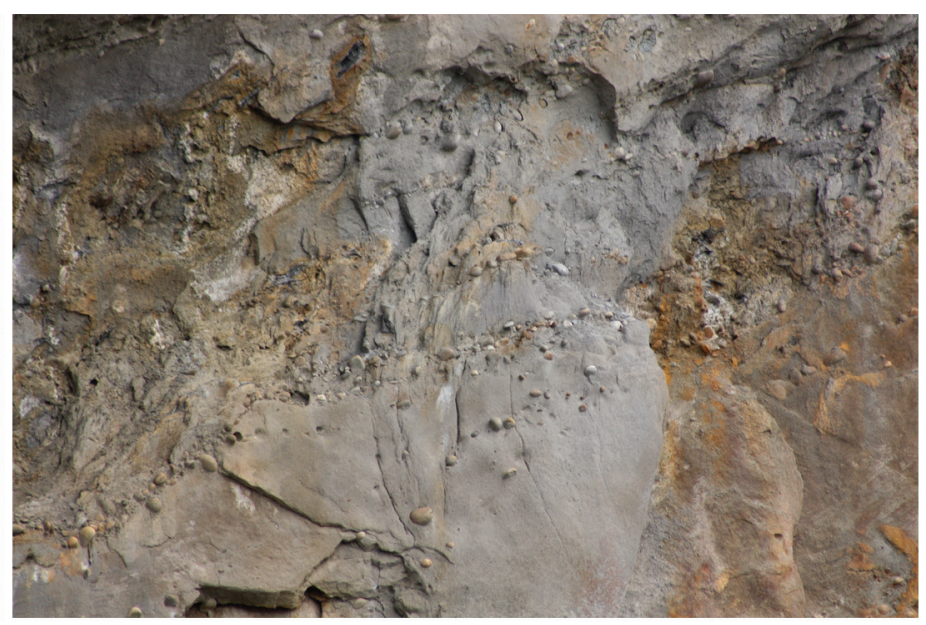

Fig. 4. Lithofacies, outcrops of Pliocene-Pleistocene Taichung Foreland basin deposits. (a) Thick black shale with fold structures of the Chinshui Shale (lithofacies Mm, FA10) exposed near the Chelungpu Fault. Hammer is $30 \mathrm{~cm}$. (b) Thick sandstone (lithofacies $\mathrm{Sg}$ ) with embedded pebbles exposed in the Toupienkengchi surface section. (c) Thick conglomerate beds exposed in the Toupienkengchi surface section, the thickness of strata of this outcrop is about $20 \mathrm{~m}$. 
(Boggs 2001). Therefore, facies association was utilized for interpretation of depositional environments. The analysis of environmental change was guided by Walther's Law (Middleton 1973; Reading 1986; Boggs 2001, 2006).

Facies analysis were carried on three measured surface sections in the Western Foothills, nine vertical outcrops on the Tatushan Tableland and cores of drilling wells (Table 1). Drilling cores (for examples of Fig. 5) and radiocarbon dating (C14) are supplied by the Central Geological Survey (CGS), Ministry of Economic Affairs, Taiwan. Lithofacies were described in detail from field investigation on outcrops and core samples in laboratory. The grain size, composition, sedimentary structures, fossils, and bedding attitudes (Reading 1986) were recorded.

Lihofacies columns with varying thickness (from 150 to $2500 \mathrm{~m}$ ) were carried out throughout the study area. The columns are arranged in depositional dip-oriented trending approximately from east (proximal) to west (distal). The lithofacies columns display vertical succession of facies and facies associations similar to that employed by Rasmussen (2000) and Ramos et al. (2002).

\section{FACIES ANALYSIS AND DEPOSITIONAL ENVI- RONMENTS}

We recognized eleven lithofacies (Table 2) based on the physical and biogenic characteristics in the strata of the Western Foothills and tablelands, and in the core samples of piggyback basin, tablelands and the Chingshui Coastal Plain in the study area. A group of lithofacies that occur together or environmentally related can be combined as a facies association. Eleven facies are grouped into ten facies associations (Table 3). The interpreted depositional environments from these facies associations include gravel-bed braided

Table 1. Drilling well sites, length, dominated lithology and biostratigraphic data of Taichung foreland basin studied in this paper.

\begin{tabular}{|l|l|c|l|l|}
\hline & Drilling well sites & Length $(\mathbf{m})$ & Dominated lithology & Calcareous Nannopfossil Zonation \\
\hline \multirow{4}{*}{ piggyback basin } & PB1: Wuri & 165 & Conglomerate & -- \\
\cline { 2 - 5 } & PB2: Dali & 200 & Conglomerate & -- \\
\hline \multirow{4}{*}{ tablelands } & TL1: Da-chia 2 & 500 & Thick shale & NN19c \\
\cline { 2 - 5 } & TL2: Rei-ching & 220 & Conglomerate, Sand & -- \\
\hline \multirow{5}{*}{ Chingshui Coastal Plain } & CP1: Kao-mei & 202 & Conglomerate, Sand & NN20-21 \\
\cline { 2 - 5 } & CP2: Ching-shuei & 150 & Conglomerate & NN21 \\
\cline { 2 - 5 } & CP3: Wu-chi & 253 & Mud and Sand & NN20-21 \\
\cline { 2 - 5 } & CP4: Chung-her & 250 & Conglomerate, Sand & NN20-21 \\
\hline
\end{tabular}

(a)

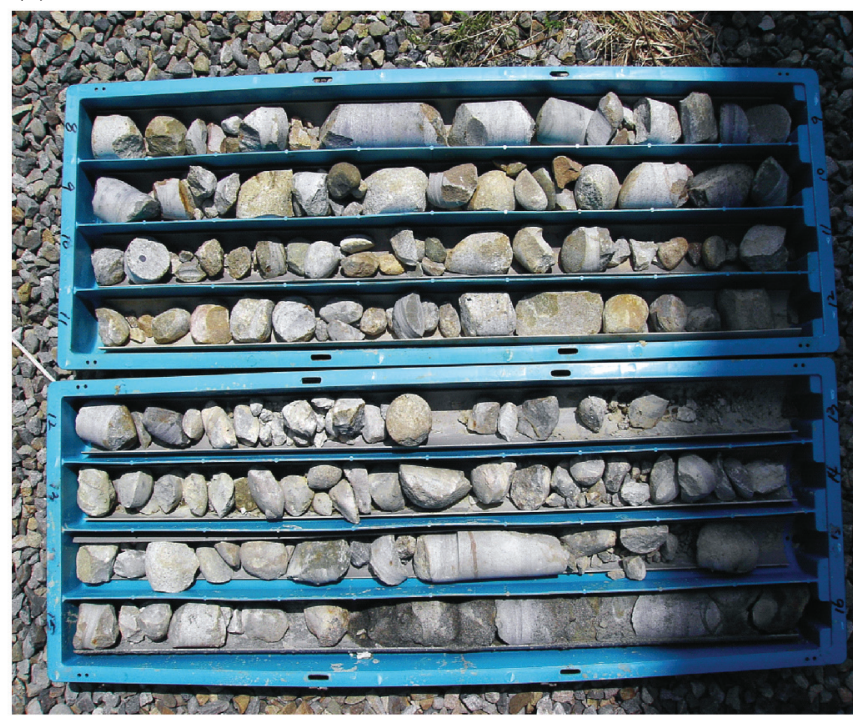

(b)

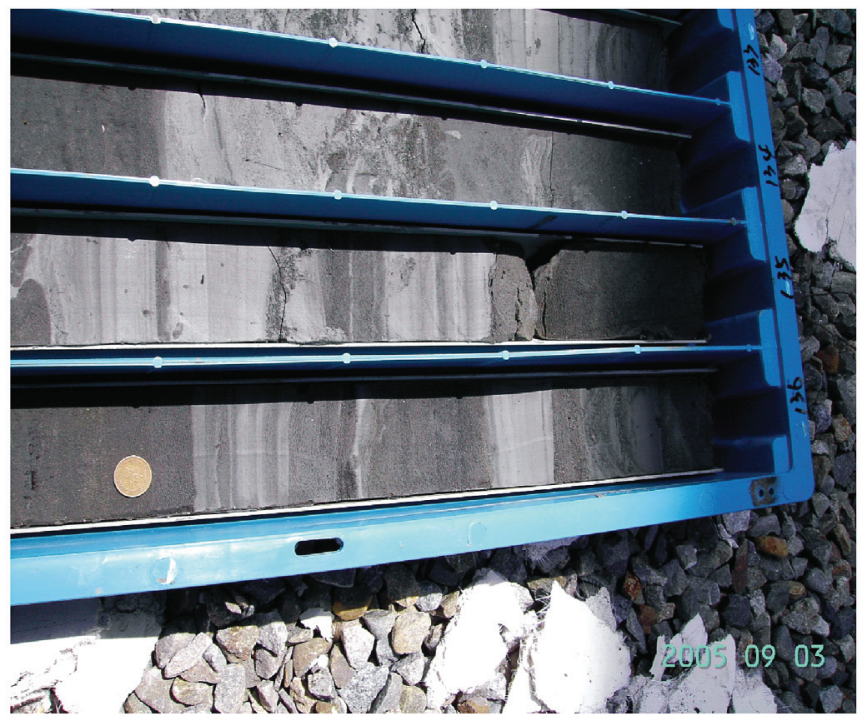

Fig. 5. Core samples of the well in the Chingshui Coastal Plain. (a) The pebble section (lithofacies Gg). (b) The mud section with parallel lamination (lithofacies $\mathrm{Mh}$ ). The coin is $2 \mathrm{~cm}$ in diameter. 
Table 2. Lithofacies list of the Taichung foreland basin.

\begin{tabular}{|c|c|c|c|c|}
\hline Facies code & Lithology & Sedimentary structures & Fossils, bioturbation & Interpreted process \\
\hline $\mathrm{Gg}$ & $\begin{array}{l}\text { massive, grain supported- } \\
\text { gravel }\end{array}$ & $\begin{array}{l}\text { crudely bedded, imbrication or } \\
\text { non-organized }\end{array}$ & none & grain-flow \\
\hline $\mathrm{Gm}$ & matrix-supported gravel & $\begin{array}{l}\text { trough cross bedding or non- } \\
\text { organized }\end{array}$ & none & grain-flow \\
\hline $\mathrm{Sm}$ & $\begin{array}{l}\text { massive, sand, fine to coarse, } \\
\text { lens mud }\end{array}$ & none & $\begin{array}{l}\text { trace fossils } \\
\text { shell fragments }\end{array}$ & fast deposit \\
\hline $\mathrm{Sh}$ & fine sand to medium & parallel lamination, LPL & Ophiomorpha sp. & sheet flood \\
\hline She & fine to medium sand & $\begin{array}{l}\text { hummocky cross stratification } \\
\text { parallel lamination, LPL }\end{array}$ & none & storm deposit \\
\hline $\mathrm{Sr}$ & medium to coarse sand & $\begin{array}{l}\text { wavy lamination, wavy cross } \\
\text { lamination }\end{array}$ & $\begin{array}{l}\text { Cylindrichnus sp. } \\
\text { Ophiomorpha sp., Thalassinoides } s p .\end{array}$ & wave dominated \\
\hline Sx & sand, medium to coarse & $\begin{array}{l}\text { Trough cross bedding, planner } \\
\text { cross bedding, LPL, }\end{array}$ & none & current flow \\
\hline $\mathrm{Sg}$ & $\begin{array}{l}\text { sand, medium to coarse, } \\
\text { pebble embedded }\end{array}$ & $\begin{array}{l}\text { Trough cross bedding, planner } \\
\text { cross bedding }\end{array}$ & none & channel flow \\
\hline SM & interbedded sand, silt, mud & $\begin{array}{l}\text { HCS, trough cross bedding, } \\
\text { flaser/wavy/lenticular bedding }\end{array}$ & $\begin{array}{l}\text { Ophiomorpha sp., } \\
\text { shell fragments }\end{array}$ & $\begin{array}{l}\text { unidirectional current, tidal } \\
\text { current }\end{array}$ \\
\hline $\mathrm{Mm}$ & massive mud & none & shell fragments & suspension, over bank \\
\hline $\mathrm{Mh}$ & mud, silt & $\begin{array}{l}\text { parallel lamination, streak silt, } \\
\text { grade }\end{array}$ & nannofossil & $\begin{array}{l}\text { suspension, over bank, waning } \\
\text { flow }\end{array}$ \\
\hline
\end{tabular}

Table 3. Facies association (FA) list.

\begin{tabular}{|c|c|c|c|}
\hline FA & lithofacies & Description & Sedimentary environment \\
\hline FA1 & $\mathrm{Gg}, \mathrm{Gm}, \mathrm{Sm}, \mathrm{Mm}$ & $\begin{array}{l}\text { Predominately Pebble to cobble, grain-supported, poorly sorted, crude or irregular } \\
\text { stratification, erosional base, multi-stories conglomerates; pebble to cobble, matrix- } \\
\text { supported, poorly sorted, trough cross bedding, erosional base conglomerates; lenticu- } \\
\text { lar sand and mud. Mud bodies contain fossil woods. }\end{array}$ & gravel-bed braided stream \\
\hline FA2 & $\mathrm{Sg}, \mathrm{Sm}, \mathrm{Mm}$ & $\begin{array}{l}\text { Predominately medium to coarse thick sands, string or spars pebbles embedded, } \\
\text { poorly sorted, trough cross bedding; intercalated thick/thin massive sand layer or mas- } \\
\text { sive mud. }\end{array}$ & sand-bed braided stream \\
\hline FA3 & $\mathrm{Gg}, \mathrm{Gm}$ & $\begin{array}{l}\text { Predominately Pebble to cobble, grain-supported or matrix-supported, poorly sorted, } \\
\text { disorder, or crude upwards fining conglomerate beds. }\end{array}$ & alluvial fan \\
\hline FA4 & $\mathrm{Sg}, \mathrm{Sh}, \mathrm{Sm}, \mathrm{Mm}$, & $\begin{array}{l}\text { Predominately medium to coarse thick sands, LPL, mud chips or pebbles in bottom } \\
\text { area, poorly sorted, erosional base; thick, crude parallel laminated mud intercalated. }\end{array}$ & meandering river \\
\hline FA5 & $\mathrm{Mm}, \mathrm{Mh}, \mathrm{Sm}$ & $\begin{array}{l}\text { Thick, massive or highly bioturbation black sand and mud interbedded. Interbedded } \\
\text { thin mud and sand with flaser/wavy/lenticular bedding, horizontal lamination, LPL. } \\
\text { Brackish bivalves or carbonaceous matters are embedded. }\end{array}$ & estuary \\
\hline FA6 & Sx, SM & $\begin{array}{l}\text { Medium to coarse thick sands contain trough and herringbone cross bedding. interbed- } \\
\text { ded thin sand, silt and mud contain flaser/wavy/lenticular bedding, spars pectons are } \\
\text { embedded, trace fossils. }\end{array}$ & tidal flat \\
\hline FA7 & $\mathrm{Sx}, \mathrm{Sh}$ & $\begin{array}{l}\text { Medium to coarse thick sands, trough and planner cross bedding, parallel lamination } \\
\text { or LPL, }\end{array}$ & foreshore \\
\hline FA8 & Sh, Shc, Sx, St & $\begin{array}{l}\text { Thick sandstones contain PLP, LPL, HCS and through cross bedding, intercalated thin } \\
\text { to medium mud; interbedded thin sand beds and mud beds. }\end{array}$ & Shoreface \\
\hline FA9 & $\mathrm{Mm}, \mathrm{Sh}, \mathrm{Shc}, \mathrm{Sr}$ & $\begin{array}{l}\text { Very thick, massive mud dominates; intercalated medium to thick sands with coquina, } \\
\text { trace fossil. }\end{array}$ & inner offshore \\
\hline FA10 & $\mathrm{Mm}, \mathrm{Shc}, \mathrm{Sm}$, & Very thick, massive mud dominates; intercalated thin storm beds. & offshore \\
\hline
\end{tabular}


stream, estuary, tidal flat, offshore, and other environments. Based on vertical succession of facies associations, we give discussion on the evolution of ancient sedimentary environments in the areas of the Western Foothills, piggyback basin, tablelands and Chingshui Coastal Plain in the Taichung foreland basin as follow.

\subsection{The Western Foothills}

The stratigraphic architecture and sedimentary facies of the Western Foothills are established based on surveys of three surface sections along three streams, Pienkengchi (SS1), Toupienkengchi (SS2), and Tungpienkengchi (SS3), respectively (Fig. 3). The best outcrop is exposed along the Toupienkengchi section (SS2). The lithofacies column (Fig. 6) is mainly based on the strata that are distributed in the Toupienkengchi section. Contact surfaces between formations are well correlated with the other two surface sections in the Pienkengchi (SS1) and the Tungpienkengchi (SS3). The stratigraphic successions are approximately $2500 \mathrm{~m}$ thick and can be divided into seven facies associations (Fig. 6). The strata are characterized by coarseningupward sequences that are characterized by thick shale in the bottom and thick conglomerate in the top. The vertical successions of facies associations, from bottom to top, are FA10, FA9, FA8, FA7, or FA6, FA2, and FA1 (Table 3). Therefore, the ancient environment of the Western Foothills was dominated by an offshore environment; which was followed subsequently by inner offshore, shoreface, foreshore or tidal flat, sand-bed braided stream facies during the lateral shift of depositional environments, and finally was filled up with sediments of gravel-braided stream. The boundary between marine and fluvial strata is at the bottom of the facies association FA2. The biostratigraphic unit of the marine strata belongs to the upper NN16 nannofossil zone (Huang 1978). The age of the unit is about $2.78 \mathrm{Ma}$ (Horng and Shea 2007). The biostratigraphic unit of the facies association F7 of the Western Foothills is about 2.4 Ma (Yang 1997). The Pleistocene fluvial strata are younger than $1.03 \mathrm{Ma}$ (Chi and Huang 1981; Chi et al. 1984; Horng and Shea 2007).

\subsection{The Piggyback Basin (Including Tablelands)}

The stratigraphic architecture and sedimentary facies of the piggyback basin were set up with analyses of core samples of the Wuri Well (PB1) and Dali Well (PB2) (Fig. 3). The core length of the PB1 is $200 \mathrm{~m}$ and the length of the PB2 is $165 \mathrm{~m}$ (Fig. 7). The lithofacies of the core of the Dali Well is dominated by facies associations FA3, which represents alluvial fan environment. The core sample of the Wuri Well shows facies associations FA1 (gravel-bed braided stream), FA3 (alluvial fan), and FA4 (meandering river) in an ascending order. The facies association FA4 implies an alluvial plain environment during earlier period in
Wuri area. The facies associations FA1 and FA3 might be a result of uplifted the Tatushan Tableland; which became a source area of transporting sediments via gravel-bed braided streams to form alluvial fans basinward in the nearby piggyback basin.

The stratigraphic architecture and sedimentary facies of the tablelands were established with field surveys of outcrops in tablelands and core samples from wells of TL1 and TL2 (Fig. 3). The core of the TL1 is approximately $420 \mathrm{~m}$ (Fig. 8a) and the TL2 is approximately $230 \mathrm{~m}$ in length (Fig. 8b). The lithofacies column of TL1 includes two facies associations FA10 and FA4 from bottom to top. Interpretation of these facies associations suggests that the sedimentary environments beneath the tablelands include the offshore and meandering river. The lithofacies column of TL2 mainly consists of the facies associations FA1. Interpretation of the facies associations FA1 suggests that the sedimentary environment of the tablelands is a gravel-bed braided stream. The contact surface of the marine and the fluvial facies is between the thick offshore shale (FA10) and the thick meandering sandstone (FA4) in TL1. This surface is referred to an unconformity because of lack of shoreface and coastal sediments. The youngest biostratigraphic unit of the top offshore strata belongs to NN19c nannofossil zone (Shieh 2006, 2008). Its age is about $1.03 \mathrm{Ma}$ (Horng and Shea 2007). The biostratigraphic unit beneath the tablelands belongs to NN19 (Ho and Chen 2000).

The vertical successions of facies associations indicate lateral shift of sedimentary environments as follows. First, the area between the Chelungpu and Tachia Faults was dominated by an offshore environment with thick marine shale. After the early Pleistocene (1.03 Ma), the offshore environment changed to a meandering river environment as a result of westward progradation of fluvial facies, finally, the environment evolved into the gravel-bed braided stream environment.

\subsection{The Chingshui Coastal Plain}

The stratigraphic architecture and sedimentary facies of the Chingshui Coastal Plain are established that based on analyses of cores of the CP1-CP4 Wells. The core length of each well is shown in Table 1. Four lithofacies columns derived from four wells, respectively, are shown separately in Fig. 9. These cores are dominated primarily by FA1 and FA5 facies associations. It is noted that fining-upward sequences of FA1 - FA5 repeat two or three times in the facies columns. The biostratigraphic unit of the lower part belongs to NN20 nannofossil zone (Shieh 2006, 2008). The age of this lower part is younger than $0.46 \mathrm{Ma}$ (Horng and Shea 2007). The biostratigraphic unit of upper part belongs to NN21 nannofossil zone. The age is younger than $0.26 \mathrm{Ma}$ (Shieh 2006, 2008). The radiocarbon dating age of the uppermost part of CP-2 well is about $4.46 \mathrm{Ka}$ (supplied by CGS). 


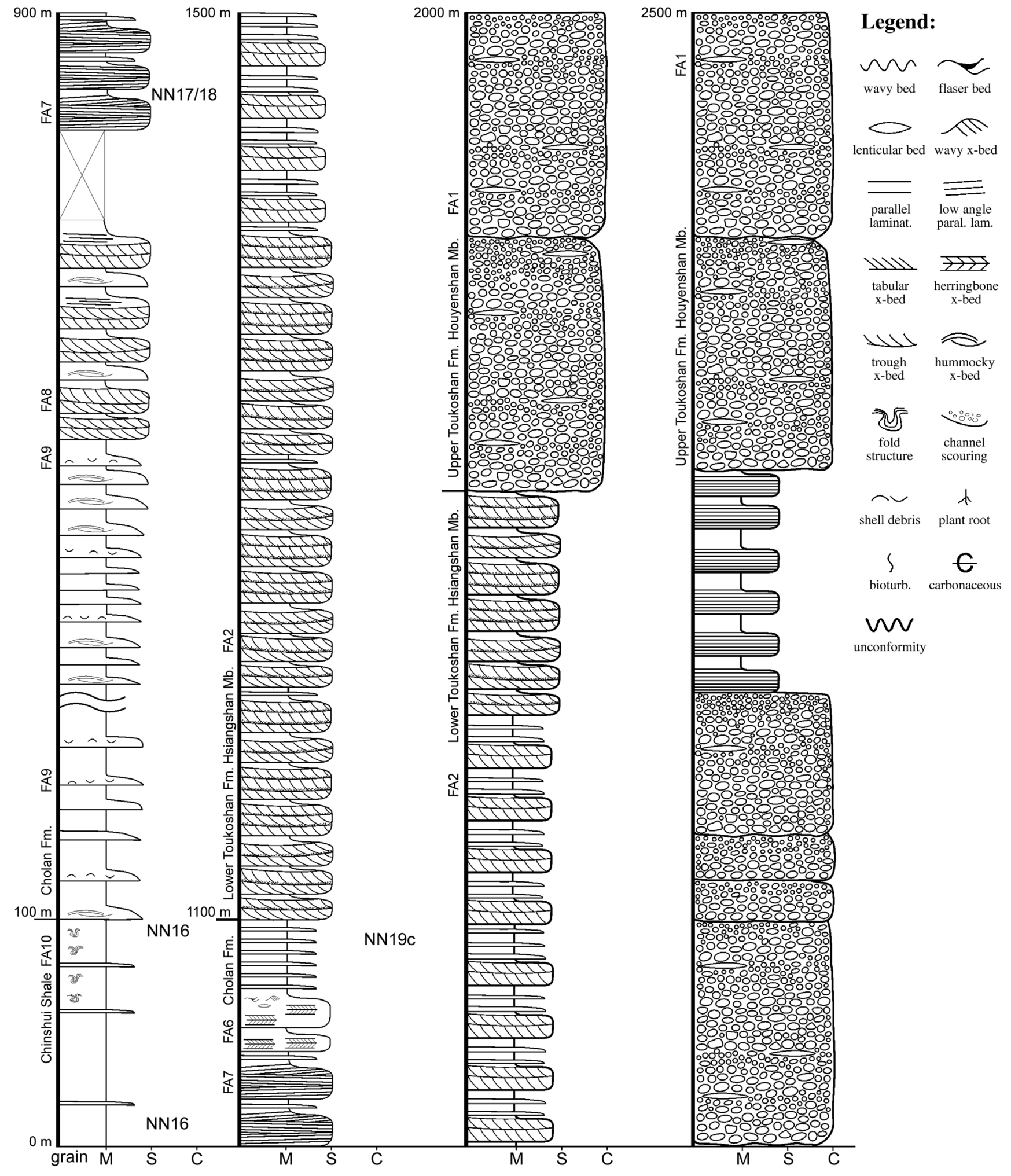

Fig. 6. Lithofacies column of the Western Foothills in the Taichung foreland basin. The construction of the stratigraphic column is mainly based on the strata that distribute in the Toupienkengchi section (Fig. 3, SS2). This column consists of the Chinshui Shale, the Cholan Formation and the Toukoshan Formation, in an ascending order. It is noted that a major change in facies at about $1100 \mathrm{~m}$ where coastal facies are overlain by fluvial sediments. 
The vertical succession of the facies associations of the Chingshui Coastal Plain indicates that the sedimentary environments were alternated between the gravel-bed braided stream and estuary settings. The facies associations of cores suggest that the ancient environment was gravel-bed braided stream at earlier period and changed to estuary setting during nannofossil zone NN20. After that, gravel-bed braided streams prevailed again. Finally, an estuary environment became dominant during nannofossil zone NN21.

\section{DISCUSSION}

Based on the evolution of sedimentary environments, westward propagation of active faults and biostratigraphy (a) PB1 well

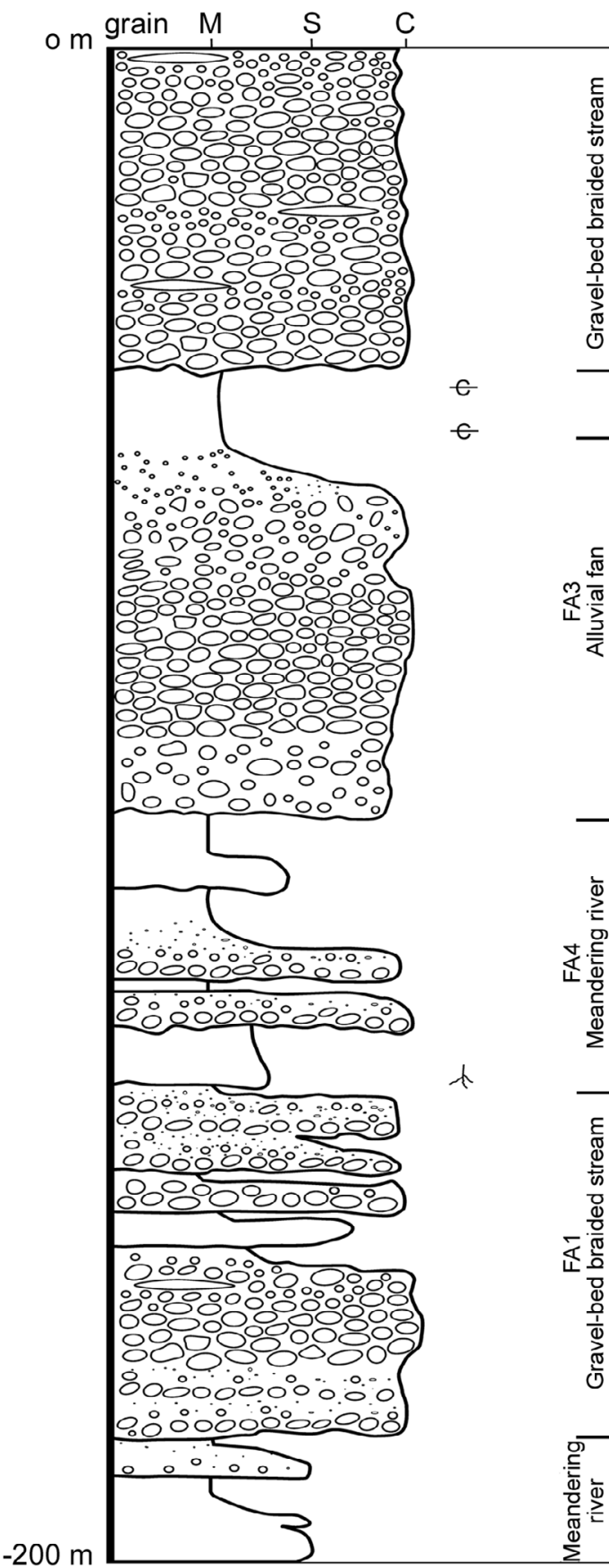

(b) PB1 well

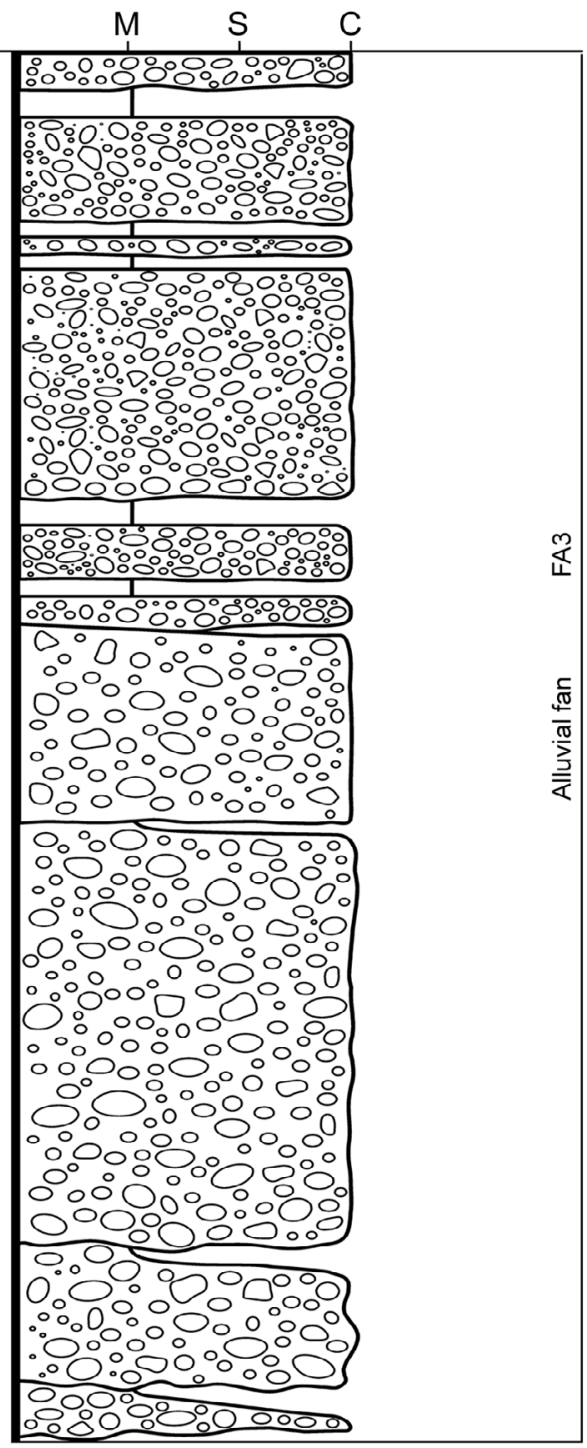

Fig. 7. Lithofacies columns of the piggyback basin in the Taichung foreland basin show lithology and sedimentary environments. The interpretation of sedimentary environment is according to the facies association of Table 3 . The core of PB1 well site contains a spatter of plant roots and carbonaceous materials, representing fully continental facies. 
(a) TL1 well

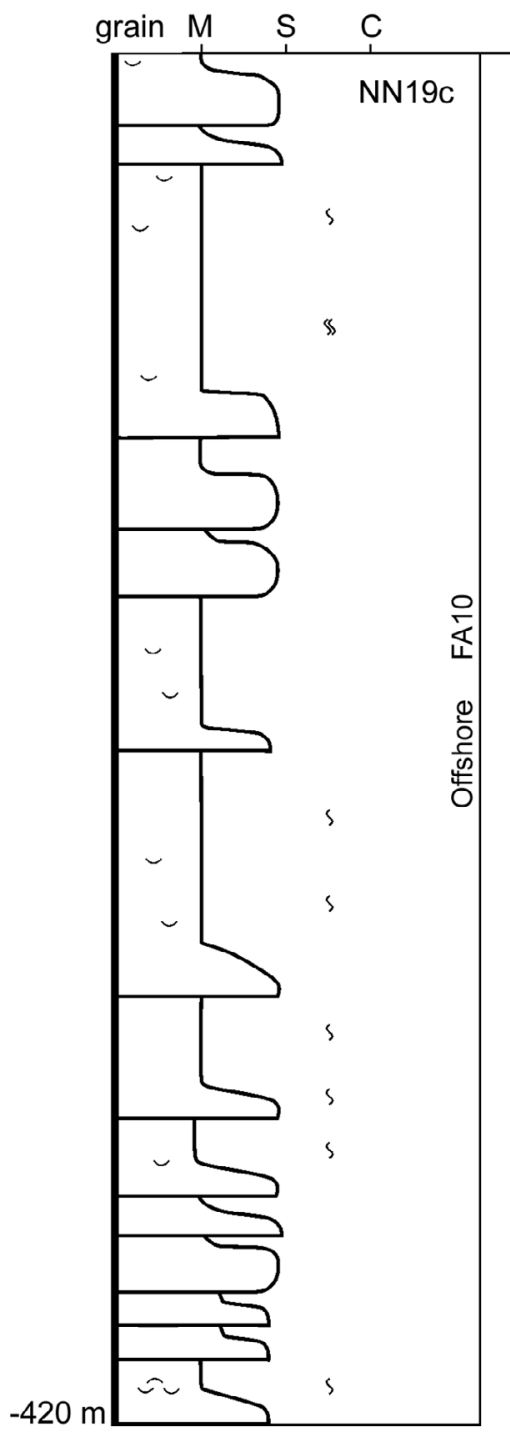

(b) TL2 well

$$
0 \mathrm{~m}^{\text {grain } \mathrm{M}} \mathrm{S} \quad \mathrm{C}
$$

\begin{tabular}{l|l|l|l|}
\hline & & 1 & $c$ \\
\hline \hline
\end{tabular}

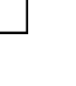


(a) CP1 well

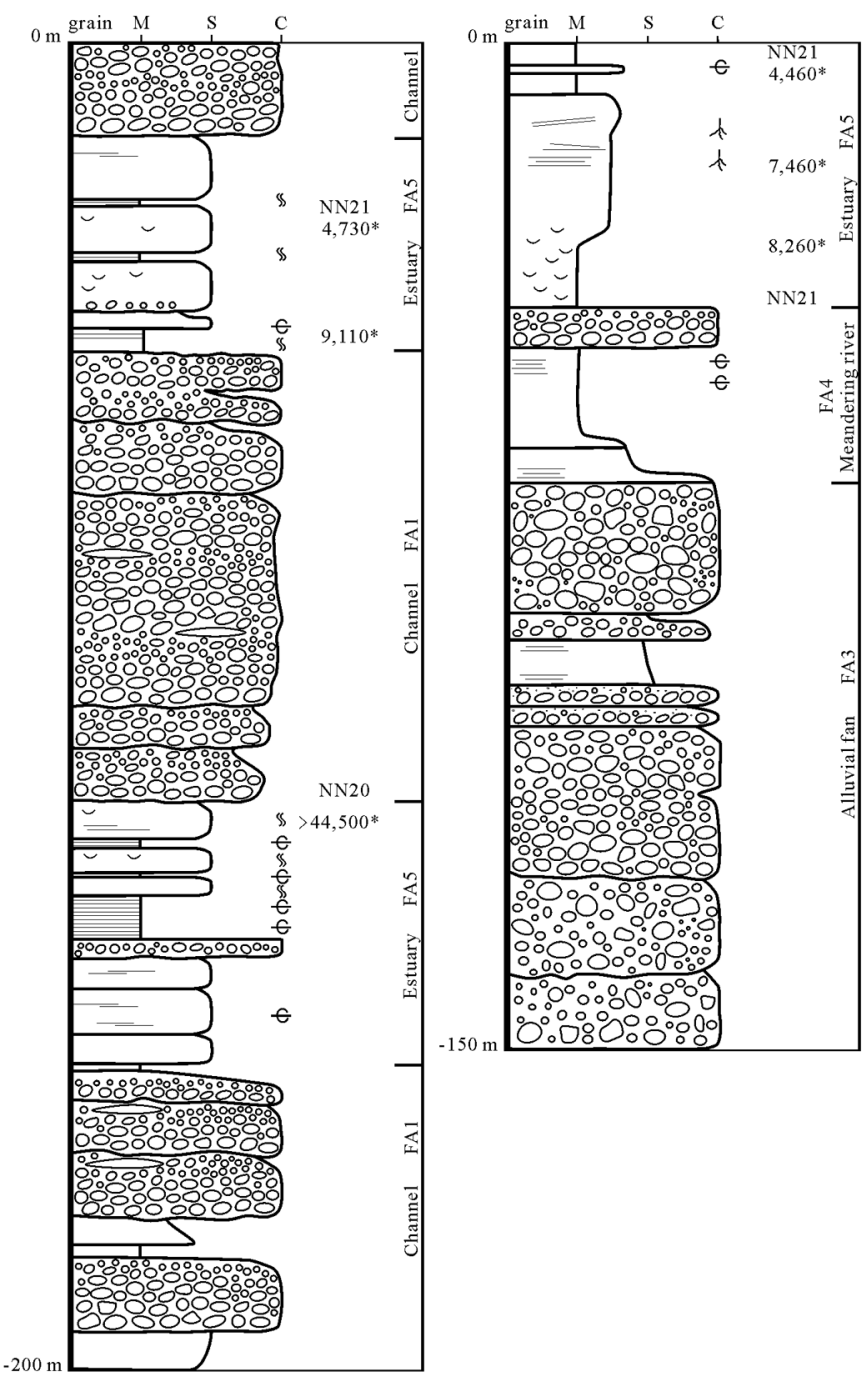

(b) CP2 well (c) CP3 well

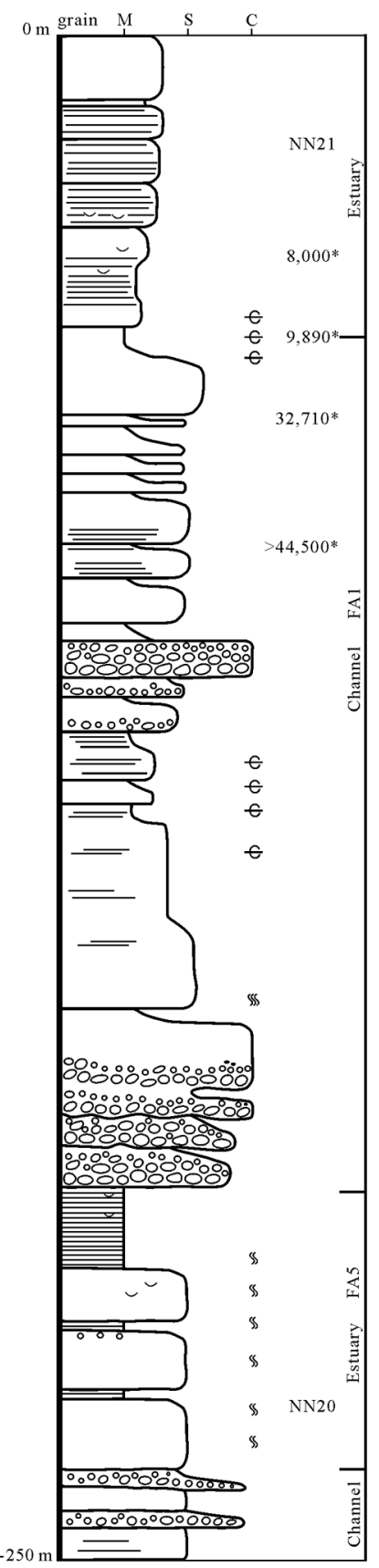

(d) CP4 well

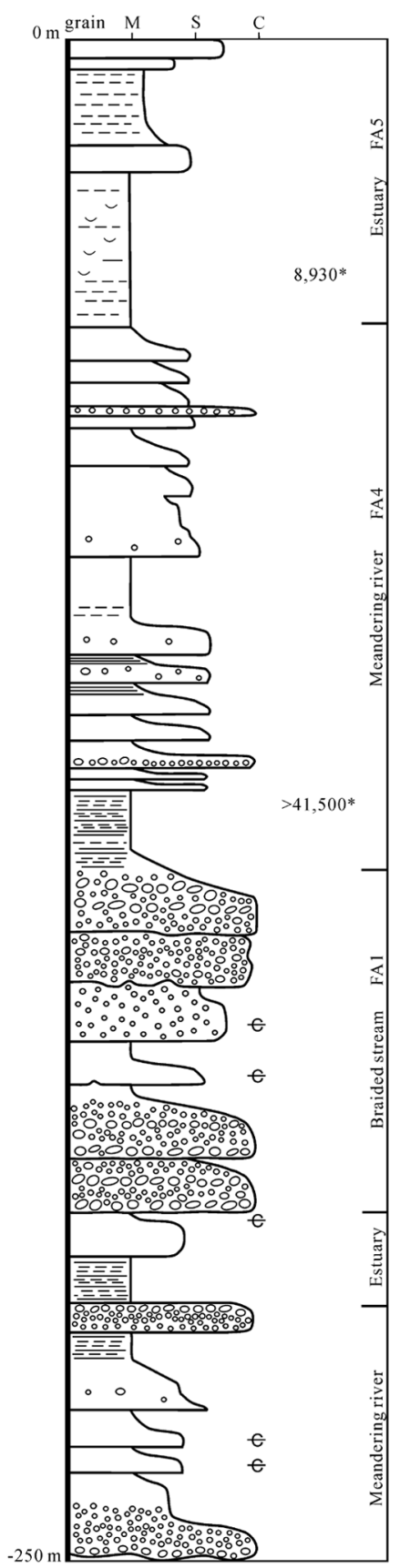

Fig. 9. Lithofacies columns of cores of wells at the Chingshui Coastal Plain in Taichung foreland basin show lithology, biostratigraphy and depositional environments. Biostratigraphic data are based on Shieh $(2006,2008)$. The radiocarbon dating age (C14) are marked by “*” that are supplied by the Central Geological Survey, MOEA. The cores contain a spatter of plant roots, carbonaceous materials and shell fragments. It is noted that alternations of fluvial channels and estuary facies occur commonly.

in study area, we give discussion on progressive westwards sediment filling and syn-depositional deformation of the Taichung foreland basin. We reconstruct a syn-deformational deposition of piggyback basin setting similar to those of Po Basin (Pliocene-Quaternary) in Italy and Ebro Basin (Eocene-Miocene) in Spain (Ori and Friend 1984).

\subsection{Underfilled Stage}

The present-day Taichung foreland basin was a marine foredeep setting prior to $2.78 \mathrm{Ma}$. This inference based on the lower part strata of the proximal (the Western Foothills, Figs. 6, 10, and 11a) and the distal parts of Taichung 


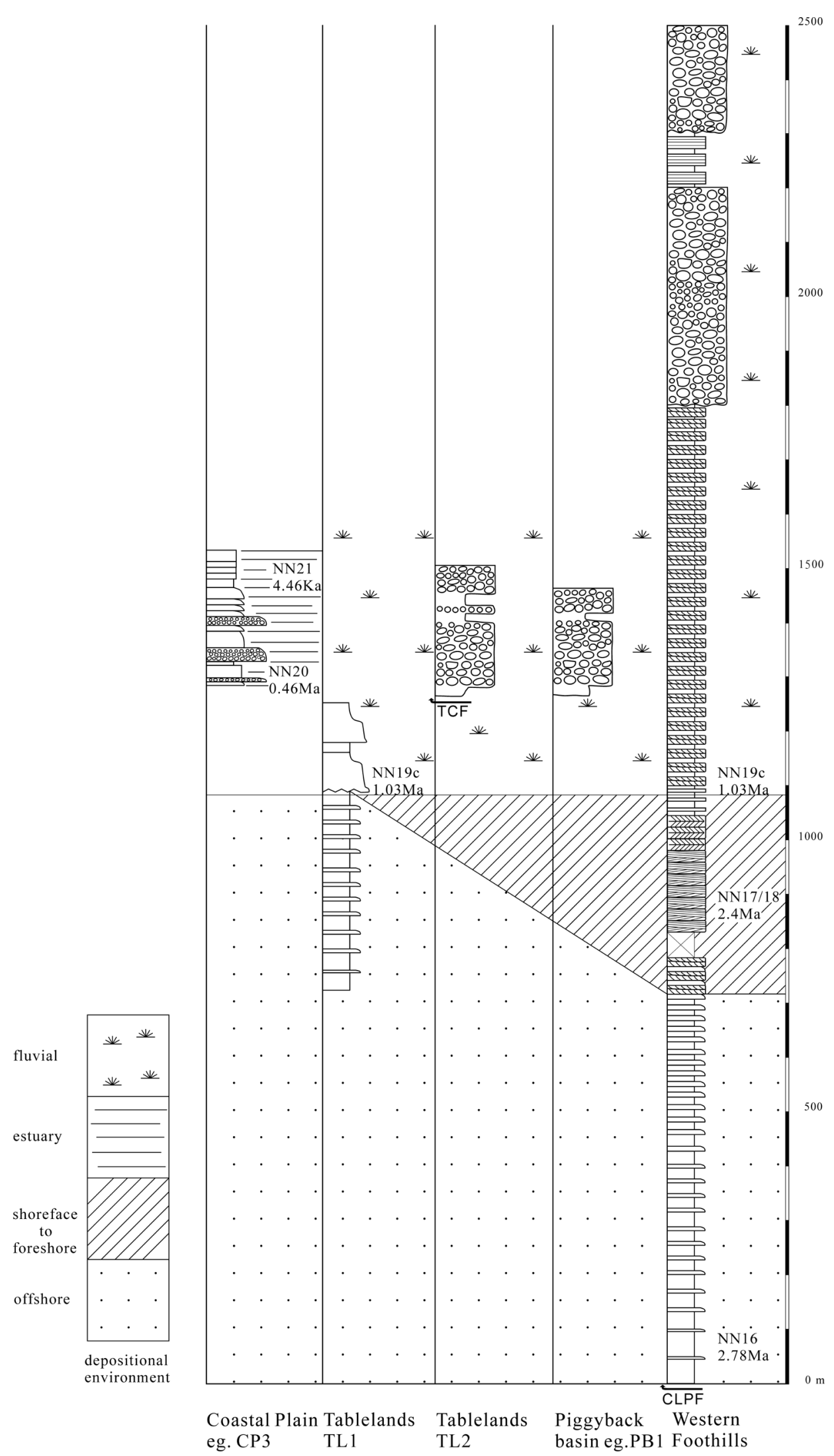

Fig. 10. Stratigraphic cross section of the Taichung foreland basin. The lithofacies column of the piggyback basin is based on the PB1 well. The lithofacies column of the Chingshui Coastal Plain is based on the CP3 well. 
NW

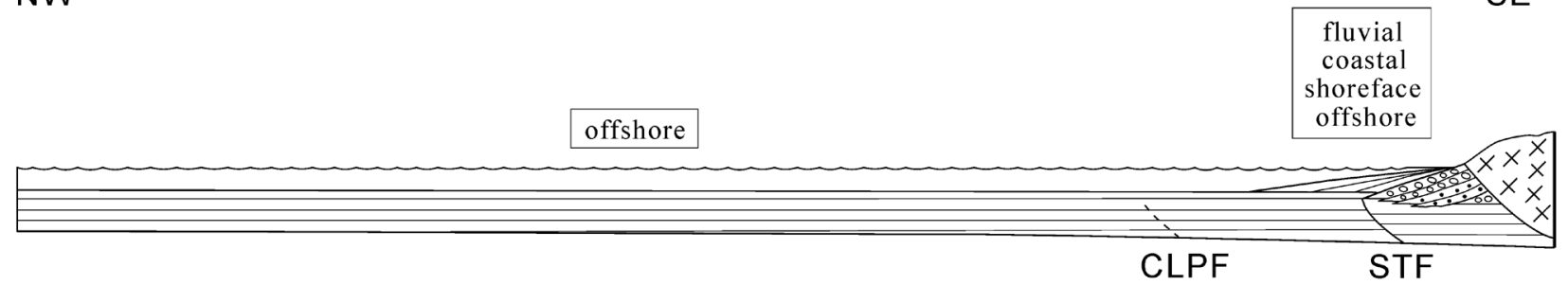

(a) $>2.78 \mathrm{Ma}$ (upper part of NN16)

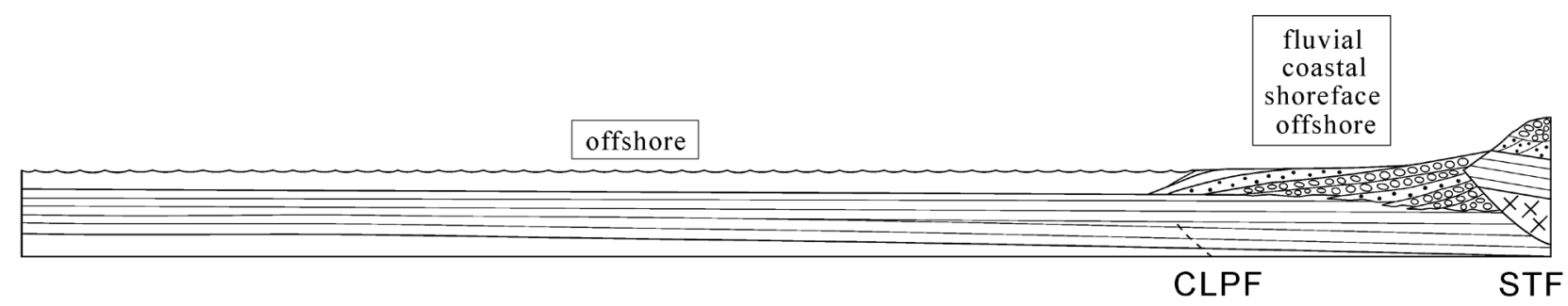

(b) $2.78 \mathrm{Ma} \sim 1.03 \mathrm{Ma}$ (upper NN16 NN19c)

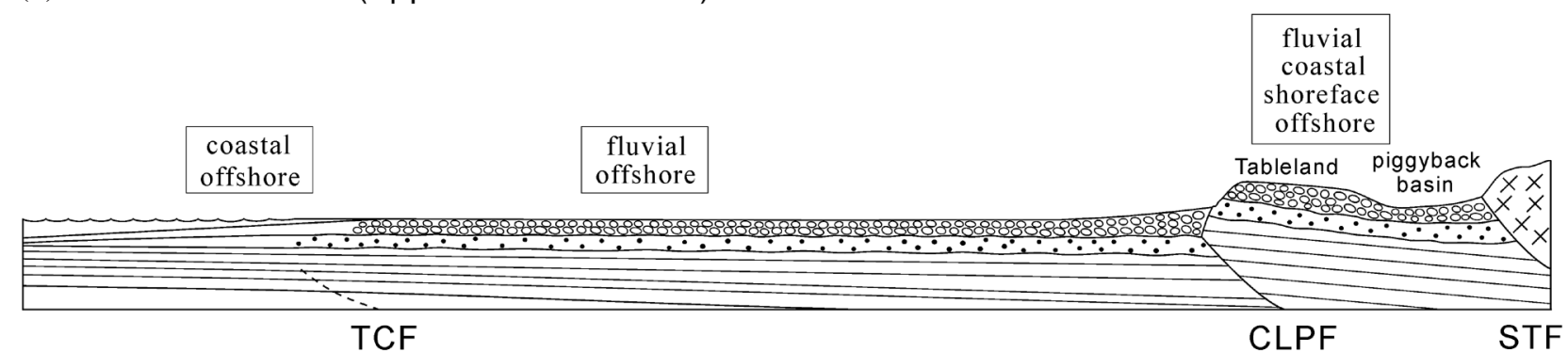

(c) $1.03 \mathrm{Ma} \sim 0.46 \mathrm{Ma}(\mathrm{NN} 19 \mathrm{c} \sim \mathrm{NN} 20)$

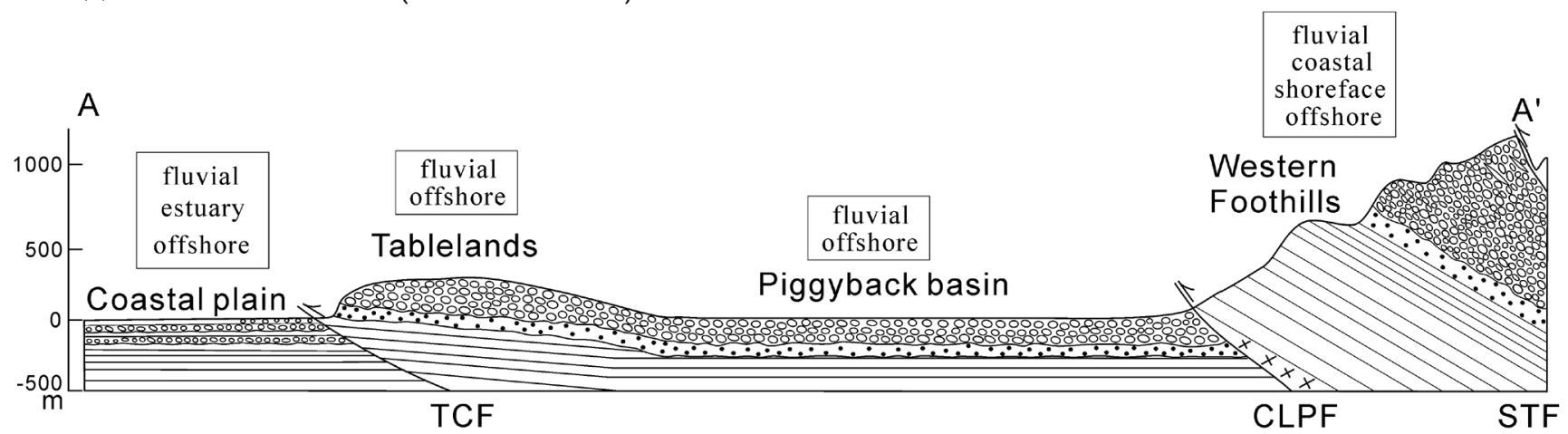

(d) $<0.46$ Ma Present (NN20 )

\begin{tabular}{|c|c|c|c|c|}
\hline & 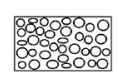 & $\because \because \because \because$ & 巨焉 & $\begin{array}{l}x \times x \times \\
x \times x x\end{array}$ \\
\hline $\begin{array}{l}\text { Fluvial } \\
\text { gravel }\end{array}$ & Tk2 & Tk1 & $\begin{array}{l}\text { Upper } \\
\text { Tertiary }\end{array}$ & Tertiary \\
\hline
\end{tabular}

\section{STF: the Shuangtung Fault, CLPF: the Chelungpu Fault, TCF: the Tachia Fault TK1: Lower Toukoshan Formation, TK2: Upper Toukoshan Formation}

Fig. 11. Schematic diagram shows a four-stage reconstruction of the Pliocene-Holocene Taichung foreland basin. (a) Underfilled stage: the Taichung foreland basin was dominated by offshore environment prior to $2.78 \mathrm{Ma}$. (b) Initial filled stage: after $2.78 \mathrm{Ma}$, the Shuangtung Fault began to thrust to form proto-foothills and the area between the Shuangtung and Chelungpu faults filled up by sediment. (c) Filled in transition to overfilled stage: about $1 \mathrm{Ma}$, the Chelungpu Fault started to thrust and uplifted the Western Foothill. The foothills supplied sediment to fill the basin between the Chelungpu and Tachia faults until $0.46 \mathrm{Ma}$. (d) Overfilled stage: after $0.46 \mathrm{Ma}$, The thrusting of Tachia Fault resulted in the formation of the tablelands and a depression in the area between the Tachia and the Chelungpu fault. The area around present Chingshui Coastal Plain began to receive sediments from eastern hinterlands and was dominated by fluvial system finally. 
foreland basin (the tablelands, Figs. 8, 10, and 11a). The lowest part of the strata of the Western Foothills consists mainly of the facies association FA10. The FA10 is interpreted as offshore marine environment. Deep marine facies corresponds to underfilled sedimentary facies of foredeep (Sinclair 1997). The biostratigraphic unit of the top part of FA10 in the Western Foothills belongs to nannofossil zone NN16, the age is about 2.78 Ma (Horng and Shea 2007). Therefore, the proximal Taichung foreland basin is inferred to be an underfilled foredeep until $2.78 \mathrm{Ma}$.

The strata of the lowest part of the tablelands consist of the facies association FA10. The biostratigraphic unit of the top part of FA10 in the tablelands belongs to nannofossil zone NN19c and the age is about $1.03 \mathrm{Ma}$ (Horng and Shea 2007; Shieh 2008). The FA10 is interpreted to be an offshore marine environment (Table 3 ). The deep marine facies in the lower part of the tablelands can be interpreted as underfilled sedimentary facies. Thus, the distal Taichung foreland basin can be inferred to be an underfilled foredeep until 1.03 Ma. The Western Foothills and tablelands with equivalent facies association FA10 are inferred to be an underfilled foredeep setting deposit about $2.78 \mathrm{Ma}$ (Figs. 6, 8, and 11a).

\subsection{Initial Filled Stage in the Proximal Parts}

After $2.78 \mathrm{Ma}$, the basin area between the STF and the CLPF has been filled up by sediments with coarsening-upward sequences (Figs. 6, 10, and 11b), whereas the foredeep in the west of the CLPF still remained offshore environment until $1.03 \mathrm{Ma}$ (Figs. 8, 10, and 11b). According to the facies associations FA8, FA7, and FA6 within the Cholan Formation in the present-day Western Foothills (Fig. 6), the depositional environments became dominated by shoreface to foreshore and coastal environments. The shoreface to foreshore and coastal environments corresponds to filled sedimentary facies (Sinclair 1997). The biostratigraphic unit of the facies association F7 suggests that the area of the present-day Western Foothills was a coastal environment at 2.4 Ma (Yang 1997). Therefore, we suggest that the basin area between the STF and the CLPF was shallow up during 2.78 - 2.4 Ma. This shallow-up process (coarsening-upward sequences) might be due to the thrusting of STF to form sediment sources (hinterlands) to the east of the STF. Those hinterlands supplied sediments to the basin area between the CLPT and the STF.

\subsection{Filled in Transition to Overfilled Stage}

The basin area between the TCF and CLPF was a fluvial environment after $1.03 \mathrm{Ma}$ (Fig. 11c). The vertical succession of TL1 of the tablelands is characterized by facies association FA10 with nannofossil zone NN19c in the lower part and FA4 in the upper part (Fig. 8a). The vertical succes- sion of TL2 of the tablelands is characterized by the facies association FA4 in the lower part and FA1 in the upper part (Fig. 8b). The facies association FA4 and FA1 are interpreted as meandering river and gravel-bed braided stream environments, respectively (Fig. 8, Table 3). Based on lithofacies column, the piggyback basin contains facies association FA1, FA3 and FA4 which are fluvial deposit (Fig. 7). The lithofacies column of PB1 (Fig. 7a) in the present-day piggyback basin contains facies associations FA1 which can be correlated with that of the tablelands in facies association. The lithofacies column of PB1 in the present-day piggyback basin shows facies association FA1 directly overlying the FA4 which can be correlated to those of TL2 well in the tablelands to the west. Although the age of these two facies association FA1 is not available, these two facies association FA1can be correlated not only in lithofaies association but also probably in chronology because no major faulting between these two wells in a relatively short distance of about $10 \mathrm{~km}$. These two facies associations FA1 can be interpreted as deposition in the gravel-bed stream environment covering the area of the present-day tablelands and piggyback basin prior to the uplifting of the TCF.

Fluvial depositional environments change in the tablelands provides implication of development of the Taichung foreland basin. The FA4 is an unconformity overlying on the FA10. This unconformity implies abundant sediments derived from the east of present-day piggyback basin. One of possibilities is westward thrusting of the CPLF to form sediment sources. The other possibility is continuing westward thrusting of the STF. The CLPF might be begin to thrust westwards about 0.7 - $1 \mathrm{Ma}$ (Chen et al. 1999, 2001a; Lee et al. 2001). The strata between the STF and CLPF were uplifted by the thrusting of the CPLF to form the proto-Western Foothills. The proto-Western Foothills supplied sediment to fill up the basin to the east of the following TCF. According to Walther's Law (Reading 1986; Boggs 2006), the sedimentary environment changed laterally from meandering river to gravel-bed stream. This change implies that coarse grains shed from the foothills to the east. The continuing westward thrusting of CLPF uplifted the strata to form the present-day Western Foothills. The Foothills produce coarse-grained sediments to be transported westwards and overlying on the meandering rivers sediment covering the present-day tablelands area prior to the thrusting of the TCF. Fluvial system corresponds to overfilled sedimentary facies (Sinclair 1997). Thus, basin area in the presentday tablelands reached overfilled stage after $1.03 \mathrm{Ma}$. The rest of the marine foredeep in the present-day Chingshui Coastal Plain has not been filled up by the fluvial sediment (Fig. 11c).

\subsection{Overfilled Stage}

The basin area in the present-day Chingshui Coastal 
Plain reached filled stage after $0.46 \mathrm{Ma}$ and reached overfilled after $4.46 \mathrm{Ka}$. The filled up processes and depositional environments in the present-day Chingshui Coastal Plain are based on the core samples of four wells. The upper parts of the lithofacies columns in the Chingshui Coastal Plain are interbedded estuary and fluvial sediments (Figs. 9, 10, and 11d). Facies association FA5 appears in the top part of lithofacies columns in CP2, CP3 and CP4 well sites. The FA5 is interpreted as an estuary environment (Table 3). Accordingly, the latest appearing depositional environment was estuary setting in the filled up stage in the Chingshui Coastal Plain (Fig. 9). The youngest age dated by the radiocarbon $\mathrm{C} 14$ is at about $9.37-4.46 \mathrm{Ka}$ (provided by CGS). The lithofaies association FA1 in top part of CP1 well site indicates a short term gravel-bed braided stream environment following the estuary environment (Fig. 9a). The fluvial system corresponds to overfilled sedimentary facies (Sinclair 1997). Therefore, the Coastal Plain area reached overfilled stage after $4.46 \mathrm{Ka}$.

The gravel-bed braided stream environment in the Chingshui Coastal Plain might be come from two sources. First is the tablelands. Second is to have communicated with the east sources of the tablelands. After $0.46 \mathrm{Ma}$, the filled foredeep was uplifted by TCF westwards thrusting and forming the present-day tablelands and piggyback basin in its east side. The inferred age of the TCF thrusting is based on the oldest biostratigraphic unit of the $\mathrm{CP} 3$ core. The oldest age of biostratigraphic unit of $\mathrm{CP} 3$ belongs to nannofossil zone NN20 and the age is about $0.46 \mathrm{Ma}$. The following strata belong to nannofossil zone NN21, the age is approximately $44.51 \mathrm{Ka}$. This vertical succession implies the strata were not eroded about $0.46 \mathrm{Ma}$ and also implies the thrusting age of the TCF was between $0.46 \mathrm{Ma}$ and $44.51 \mathrm{Ka}$. The second sources of gravel-bed braided stream in the Chingshui Coastal Plain were major connection through its northern and southern margin that probably corresponded to lower lateral ramp. Those two streams have communicated with the present-day piggyback basin and eastern sedimentary sources.

The Taichung foreland basin has been progressively filled up by orogenic sediments since $2.78 \mathrm{Ma}$. The filled basin has been deformed by westwards thrusting faults. The Taichung foreland basin has been filled up with sediments derived from the hinterland to the east of the STF. The orogenic sediments have been transported to the present-day shoreline. The thrusting CLPF uplifted the strata between the STF and the CLPF and formed the present-day Western Foothills. Subsequently, thrust faults propagated westward in the Taichung basin. The TCF uplifted the strata in the distal part of Taichung foreland basin after $0.46 \mathrm{Ma}$ and formed tablelands.

The Taichung foreland basin consists of two piggyback basins which are formed and carried by active thrust sheets as analogous to the Po and Ebro basins in Europe
(Ori and Friend 1984). The older piggyback basin bounded by the CLPF and the STF is filled up by coarsening upward sediments beginning from bottom offshore facies to fluvial sediments at top. This piggyback basin is uplifted primarily by the westward propagating the CLPF to become as a part of the Western Foothills (Fig. 11d). The present piggyback basin confined between the TCF and the CLPF is filled up by Pleistocene offshore facies in lower part and unconformably overlain by sandy fluvial sediments in the middle part and coarse-grained gravels at the top. It is carried by the thrust sheet that bounded by the TCF and the CLPF westward to become the uplifted tablelands distal to the Western Foothills (Fig. 11d).

\section{CONCLUSION}

We examined three surface sections, nine outcrops and cores from eight wells in the Taichung foreland basin. Eleven lithofacies are recognized and grouped into ten facies associations to reveal various depositional environments in the study area. The oldest strata of the Taichung foreland basin are Pliocene in the proximal Western Foothills to the east, whereas the youngest deposits are found to be Holocene in the distal coastal plain to the west. The sequentially westward thrusting of active faults had taken place from Pliocene to Pleistocene accompanied by syn-deformational deposition.

A reconstruction of the four stages of development of the Pliocene-Holocene Taichung foreland basin is attempted here. First, the whole foreland basin was in underfilled stage. Prior to $2.78 \mathrm{Ma}$, the Tertiary rocks to the east of the Shuangtung Fault contributed little sediment to the presentday Taichung foreland basin which then was dominated by offshore environment. Second, after $2.78 \mathrm{Ma}$, the Shuangtung Fault began to thrust westward to uplift the Tertiary rocks, forming the proto-foothills. The foothills supplied fluvial sediments to the west to fill up the marine basin till about $1 \mathrm{Ma}$ before the Chelungpu fault began to thrust westward. The basin between the Shuangtung and Chelungpu Faults was in an initial filled stage containing coarseningupward facies, whereas the basin to the west of the Chelungpu Fault continued to remain in an offshore environment. Subsequently, about 0.7 - $1 \mathrm{Ma}$, the Chelungpu Fault began to thrust westward and continued. The thrusting of the CLPF resulted in uplifting and deforming the strata between the Chelungpu and Shuangtung faults to build the present-day Western Foothills. The Foothills supply fluvial sediment to fill up the basin to the west to be in transition to overfilled stage. The latest one is overfilled stage. The Tachia Fault began to thrust after $0.46 \mathrm{Ma}$ and resulted in the formation of the Tatushan and Houli tablelands and a piggyback basin in the area between the Tachia and the Chelungpu faults. The rest of the basin to the west of the Tachia Fault began to receive fluvial sediments from the east and was filled up. 
Finally, the basin to the west of tablelands was completely filled with fluvial sediments and became the present $\mathrm{Ch}$ ingshui Coastal Plain. The entire Taichung foreland basin reached overfilled stage after $4.46 \mathrm{Ka}$. The development of Taichung foreland basin and its characteristic of thrusting faults can be analogous to the development of piggyback basins of the Po Basin in Italy and Ebro Basin in Spain.

Acknowledgements We thank the Central Geological Survey, Ministry of Economic Affairs, Taiwan, to support this project of investigation of the Taichung foreland basin. We thank Ying Tzung Shieh who provides biostratigraphic data used in this study. We thank Kai-Shuan Shea for reviewing early draft of manuscripts.

\section{REFERENCES}

Boggs, S. Jr., 2001: Principles of Sedimentology and Stratigraphy. $3^{\text {th }}$ edition, Prentice Hall, New Jersey, 726 pp.

Boggs, S. Jr., 2006: Principles of Sedimentology and Stratigraphy. $4^{\text {th }}$ edition, Prentice Hall, New Jersey, 662 pp.

Chen, W. S., C. H. E, M. M. Chen, C. C. Yang, I. S. Chang, and T. K. Liu, 1999: The evolution of foreland basins in the Western Taiwan: Evidence from the Plio-Pleistocence sequences. Bull. Cent. Geol. Surv. MOEA, 13, 137-156. (in Chinese)

Chen, W. S., C. C. Yang, B. S. Huang, Y. G. Chen, R. C. Shih, Y. H. Lee, H. C. Chang, N. W. Huang, C. C. Lin, S. H. Sung, and K. J. Lee, 2001a: Characteristics of thrust system in relation with the 1999 Chi-chi earthquake ruptures in the western foothills, central Taiwan. Ti-Chih, 21, 19-36.

Chen, W. S., K. D. Ridgway, C. S. Horng, Y. G. Chen, K. S. Shea, and M. G. Yeh, 2001b: Stratigraphic architecture, magnetostratigraphy, and incised-valley systems of the Pliocene-Pleistocene collisional marine foreland basin of Taiwan. Geol. Soc. Am. Bull., 113, 1249-1271, doi: 10.1130/0016-7606(2001)113<1249:SAMAIV>2. $0 . \mathrm{CO} ; 2 .[\underline{\mathrm{Link}}]$

Chi, W. R. and H. M. Huang, 1981: Nannobiostratigraphy and paleoenvironments of the late Neogene sediments and their tectonics implications in the Miaoli area, Taiwan. Petrol. Geol. Taiwan, 18, 111-129.

Chi, W. R., W. W. Mei, and J. C. Wu, 1984: Neogene nannoplankton biostratigraphy of Miaoli-Taichung area. Bull. Explor. Dev. Res. Inst., 7, 52-68. (in Chinese)

Chiang, C. S., H. S. Yu, and Y. W. Chou, 2004: Characteristics of the wedge-top depozone of the southern Taiwan foreland basin system. Basin Res., 16, 65-78, doi: 10.1111/j.1365-2117.2004.00222.x. [Link]

Chou, Y. W. and H. S. Yu, 2002: Structural expressions of flexural extension in the arc-continent collisional foredeep of western Taiwan. Geol. Soc. Am. Spec. Paper, 358, 1-12, doi: 10.1130/0-8137-2358-2.1. [Link]
Covey, M., 1984: Lithofacies analysis and basin reconstruction, Plio-Pleistocene western Taiwan foredeep. Petrol. Geol. Taiwan, 20, 53-83.

Covey, M., 1986: The evolution of foreland basins to steady state: evidence from the western Taiwan foreland basin. In: Allen, P. A. and P. Homewood (Eds.), Foreland Basins, Special Publication of the International Association of Sedimentologists 8, 77-90, doi: 10.1002/978 1444303810.ch4. [Link]

DeCelles, P. G. and K. A. Giles, 1996: Foreland basin systems. Basin Res., 8, 105-123, doi: 10.1046/j.1365-21 17.1996.01491.x. [Link]

Dickinson, W. R., 1974: Plate tectonics and sedimentation. In: Dickinson, W. R. (Ed.), Tectonics and Sedimentation, SEPM Special Publication 22, 1-27.

Ho, C. S., 1986: A synthesis of the geologic evolution of Taiwan. Tectonophysics, 125, 1-16, doi: 10.1016/00401951(86)90004-1. [Link]

Ho, S. C. and M. M. Chen, 2000: Geologic Map of Taiwan Scale 1:50000 and Explanatory Text: 24 Taichung, Cent. Geol. Surv., MOEA, Taiwan, 65 pp.

Horng, C. S. and K. S. Shea, 2007: The Quaternary magentobiostratigraphy of Taiwan and Penglai orogenic events. Spec. Publ., Cent. Geol. Surv., MOEA, 18, 5183. (in Chinese)

Huang, T., 1978: Significant new look on the Tertiary stratigraphy of Taiwan. Petrol. Geol. Taiwan, 15, 167179.

Huang, T., 1981: An attempt for absolute chronology of Neogene in Taiwan by biostratigraphic correlation. $\mathrm{Ti}$ Chih, 3, 135-137. (in Chinese)

Kumar, R., S. K. Ghosh, R. K. Mazari, and S. J. Sangode, 2003: Tectonic impact on the fluvial deposits of PlioPleistocene Himalayan foreland basin, India. Sediment. Geol., 158, 209-234, doi: 10.1016/S0037-0738(02)00 267-1. [Link]

Lee, J. C., Y. G. Chen, K. Sieh, K. Mueller, W. S. Chen, H. T. Chu, Y. C. Chan, C. Rubin, and R. Yeats, 2001: A vertical exposure of the 1999 surface rupture of the Chelungpu fault at Wufeng, western Taiwan: Structural and paleoseismic implications for an active thrust fault. Bull. Seismol. Soc. Am., 91, 914-929, doi: 10.17 85/0120000742. [Link]

Lee, Y. H., K. S. Shea, T. Huang, H. C. Ho and W. H. Chen, 1997: Evolution of southwest Taiwan foreland basin. Proceedings and abstracts of the $4^{\text {th }}$ Symposium on Stratigraphy of Taiwan, Geology of Southwest Taiwan, 6473.

Lin, A. T. and A. B. Watts, 2002: Origin of the West Taiwan basin by orogenic loading and flexure of a rifted continental margin. J. Geophys. Res., 107, 2185, doi: 10.1029/2001JB000669. [Link]

Lin, C. W., S. T. Lu, T. S. Shih, W. H. Lin, Y. C. Liu, and P. T. Chen, 2008: Active Faults of Central Taiwan and 
Explanatory Text for the Strip Maps of Active Faults Scale 1:25000, Cent. Geol. Surv., MOEA, Taiwan, $148 \mathrm{pp}$.

Middleton, G. V., 1973: Johannes Walther's Law of the correlation of facies. Geol. Soc. Am. Bull., 84, 979-988, doi: 10.1130/0016-7606(1973)84<979:JWLOTC>2.0. CO;2. [Link]

Ori, G. G. and P. F. Friend, 1984: Sedimentary basins formed and carried piggyback on active thrust sheets. Geology, 12, 475-478, doi: 10.1130/0091-7613(1984) 12<475:SBFACP>2.0.CO;2. [Link]

Ramos, E., P. Busquets, and J. Vergés, 2002: Interplay between longitudinal fluvial and transverse alluvial fan systems and growing thrusts in a piggyback basin (SE Pyrenees).Sediment.Geol., 146, 105-131, doi: 10.1016/ S0037-0738(01)00169-5. [Link]

Rasmussen, H., 2000: Nearshore and alluvial facies in the Sant Llorenç del Munt depositional system: Recognition and development. Sediment. Geol., 138, 71-98, doi: 10.1016/S0037-0738(00)00144-5. [Link]

Reading, H. G., 1986: Sedimentary Environments and Fa- cies, Blackwell Scientific Publications, London, 615 pp.

Shieh, Y. Z., 2006: Ground Water Survey Project of Taiwan: Correlation of Biostratigraphy and Stratigraphy (3/3), Cent. Geol. Surv., MOEA, Taiwan, 214 pp.

Shieh, Y. Z., 2008: Ground Water Survey Project of Taiwan: Correlation of Biostratigraphy and Implication of Sedimentary Environments (2/2), Cent. Geol. Surv., MOEA, Taiwan, 234 pp.

Sinclair, H. D., 1997: Tectonostratigraphic model for underfilled peripheral foreland basins: An Alpine perspective. Geol. Soc. Am. Bull., 109, 324-346, doi: 10.1130/ 0016-7606(1997)109<0324:TMFUPF>2.3 .CO;2. [Link]

Suppe, J., 1981: Mechanics of mountain-building and metamorphism in Taiwan. Mem. Geol. Soc. China, 4, 6789.

Yang, C. C., 1997: Depositional environments of the Chinshui shale, Cholan and Toukoshan formations, central Taiwan. Master Thesis, Department of Geosciences, National Taiwan University, 120 pp. 